\title{
The Influence of Macroeconomic Variables on Health Indices, Murder and Mortality: A Case of Jamaica
}

Paul Andrew Bourne ${ }^{1 *}$, Mark Mills ${ }^{2}$, Janinne Campbell-Smith ${ }^{3}$, Charlene Sharpe-Pryce ${ }^{4}$, Cynthia Francis $^{5}$, Ikhalfani Solan ${ }^{6}$ and Angela Hudson Davis ${ }^{7}$

${ }^{1}$ Socio-Medical Research Institute, Jamaica

${ }^{2}$ Criswell College, Dallas Texas, 4010 Gaston Avenue Dallas, TX 75246, USA

${ }^{3}$ Cable and Wireless Company, Jamaica

${ }^{4}$ Chair, Department of History, Northern Caribbean University, Mandeville, Jamaica

${ }^{5}$ University of Technology, Jamaica

${ }^{6}$ Department of Mathematics and Computer Science, South Carolina State University

${ }^{7}$ Capella University, USA

\begin{abstract}
Background: A paucity of information exists in the literature that has seen a single study modeling macroeconomic indicators, murder and health indices (i.e., illness rate, health insurance coverage, health care utilization and mortality) in the English-speaking Caribbean. The current paper fills the gap in the literature.

Objective: This paper examines how selected macroeconomic variables influence murder, mortality and illhealth.

Methods: The data for this study are taken from publications of different governmental organizations, responsible for the collection of pertinent data for the government to carry out policy planning. Ordinary least square regression analyses were used to establish the model for 1) mortality, 2) murder and 3) ill-health.

Results: There is a fluctuation of murder rates between the decades in the study period as evidenced by the fact that the average number of murders in Jamaica between 1969 and 1981 was 266. The following decade (1980-1989) saw an $85.3 \%$ increase, which subsequently saw a $43.4 \%$ reduction by the third decade of the study period (1990-1999). The last decade (2000-2009) saw a $93.5 \%$ increase in murders. For the studied period, there was a geometric progression in murders compared to a cyclical change in mortality. There was a strong correlation between murder and health insurance coverage $\left(r_{s}=0.960 ; P=0.0001\right)$, inflation $\left(r_{s}=-0.861 ; P=0.0001\right)$, exchange rate $\left(\mathrm{r}_{\mathrm{s}}=0.950 ; P=0.0001\right)$; a moderate relationship between mortality and health care utilization $\left(\mathrm{r}_{\mathrm{s}}=0.654 ; P=0.001\right)$ and no bivariate relationship existed between murder and illness $\left(r_{s}=-0.411, P=0.090\right)$.
\end{abstract}

Conclusion: The reality is government should have a coherent policy in place to address these events, as every life lost through murder is important and represents a reduction in potential contribution to economic growth and development.

Keywords: Exchange rate; Illness rate; Health; Health insurance; Health care utilization; Inflation; Jamaica; Mortality; Murder; Poverty rate; Unemployment rate

\section{Introduction}

Crime and violence are major problems faced by Jamaicans, which dates back to pre-independence. Politics brought new dimensions to the matters that have been exasperated since the 1940s and more so in the 1970s during the Cold War, political and ideological divisiveness. The crime problem had reached an alarming proportion in the Caribbean that prompted a conference in 1998, which was hosted in Barbados on 'Crime and Criminal Justice in the Caribbean' in order to ascertain measures, policies, programmes, and intervention that can be instituted to remedy the pandemic. Using data from a crosssectional probability survey in 2007 , a group of researchers found that $11 / 25$ Jamaicans indicated that crime and violence were the number one national problem followed by unemployment [1]. Another author stated that "The problem of crime in the Caribbean - its causes, its consequences, and its control - emerged as a major concern during the 1990s" [2], suggesting that this problem extends beyond Jamaica to the wider Caribbean region. Statistics dating back to early nineteenth century established that crime and violence have some tenets that emerged during slavery [3].

Simmonds postulated that social inequalities in the plantation society were among the reasons for criminal activities in Jamaica as the slaves sought to topple the 'aristocracy' establishment [3]. The economic marginalization of the peasants, income inequality, social exclusions and economic progress of the bourgeoisie (planters) class, during slavery, provide justification for social deviances [3]. In most post-independent Caribbean nations, aside from slavery, the origin of crime and violence in the Caribbean has been attributed to the issue of police abuse [4,5], social inequalities [6], poverty and politics [7-9].

Akin to the social, political, economic and historical context of crimes in Jamaica, the fear of crime and victimization has muted many people [10] and, concomitantly, criminals are left to repeatedly perpetrate their acts. This is typically the case in other Caribbean

*Corresponding author: Paul Andrew Bourne, Director, Socio-Medical Research Institute, 66 Long Wall Drive, Stony Hill, Kingston 9, Kingston, Jamaica, Tel: (876)5663088; E-mail: paulbourne1@yahoo.com, paulbourne1@gmail.com

Received December 04, 2013; Accepted January 20, 2014; Published January 25,2014

Citation: Bournev PA, Mills M, Campbell-Smith J, Sharpe-Pryce C, Francis C, et al. (2014) The Influence of Macroeconomic Variables on Health Indices, Murder and Mortality: A Case of Jamaica. J Gen Pract 2: 145. doi: 10.4172/2329-9126.1000145

Copyright: ( 2014 Bournev PA, et al. This is an open-access article distributed under the terms of the Creative Commons Attribution License, which permits unrestricted use, distribution, and reproduction in any medium, provided the original author and source are credited. 
nations like Trinidad and Tobago [11] as well as some non-Caribbean nations [12-14]. There has been a plethora of studies on the typology of crime, victimization, fear factors and the historical tenets of crimes in particular geopolitical zones [2-7,12-14] as well as the availability of guns and their usage in suicides $[15,16]$. However, given the high rates of crime particularly in Jamaica and Trinidad and Tobago, no study has examined links between murder, mortality, health, health care utilization and selected macroeconomic indicators such as inflation, poverty, gross domestic product (GDP per capita growth), and the exchange rate. Harriott, a Caribbean criminologist, has suggested that the problem of crime in the region has resulted in extensive public policy concerns as well as quest for solutions [17]. He stated that "While policy should be informed by an appreciation of the problem involving at least an analytic description of it, policy elaboration need not await a definitive analysis of its sources or the causes" [17]. Embedded in Harriott's perspective is the value of research in the policy process. This ideology highlights not only the importance of inquiry in decision making process, but speaks to the handicap in not having pertinent information on issues that cause, explain and determine behaviour in an effort to curtail crime.

Murder which is a crime has never been studied as a cause of death or public health phenomenon as hypertension, arthritis, diabetes and other causes of mortality in the Caribbean, particularly Jamaica. A paucity of information exists in literature that points to a single study coalescing 1) murder, 2) macroeconomics indicators (poverty rate, inflation rate, unemployment rate and GDP per capita), and 3) health indices (illness rate, health insurance coverage, health care utilization and mortality) in the English-speaking Caribbean. This paper, having recognized the limitations of the literature, evaluates the changing nature of murder, mortality, illness, and selected macroeconomic variables in Jamaica, and the correlation as well as model trends in order to ascertain explanations and determine functionality.

\section{Empirical and theoretical framework}

Using national data for Jamaica, a Caribbean scholar, empirically linked health and murder as well as established the correlates of health by way of utilizing selected macroeconomic indicators and annual murders. Bourne [18] modeled illness rate using murder and selected macroeconomic indicators, GDP and unemployment, which is fitting for this research. It was established that illness rate is a function of GDP, unemployment and murders noted in Equation [1]:

$$
I_{t}=f\left(G D P, U_{t}, M_{t}\right)+e_{t}
$$

Where GDP is Gross domestic product growth, $U_{t}$ denotes unemployment, $\mathrm{M}_{t}$ is number of murders, and $e_{t}$ is the random error.

Not only did Bourne model illness rate utilizing macroeconomic indicators and murder, we established an illness function, using annual illness rates and murder. The illness function with murder being the only independent variable is expressed in Equation [2]:

$$
I_{t}=\beta_{0}+\beta_{1} X_{t}+\beta_{2} X_{t}^{2}+\beta_{3} X_{t}^{3}+e_{t}
$$

Where $\beta_{0}$ is a constant and $\beta_{2-3}$ are parameters of variable $X, X$ is murder and $t$ denotes time and $e_{t}$ is the random error.

With Bourne's work on health and murder as well as selected macroeconomic indicators, this set the premise for the expansion of health indices, macroeconomic indicators and crimes. Classical Linear Regression models attempt to assess the relationship between a single dependent variable and explanatory (or independent) variables, which are in keeping with Bourne's model of illness rate. Hence this forms the basis for the interpretation and application of the work. We have expanded on the work of Bourne [18], even as it relates to health to include mortality and another health indicator, health care utilization, to include modeling mortality and murder.

For this study, three hypotheses will be test, which are expressed in Equations [1-3]:

$$
\begin{aligned}
& \mathrm{M}=\mathrm{f}(\mathrm{U}, \mathrm{E}, \mathrm{GDP}, \mathrm{I}, \text { Mor, } \mathrm{I}) \\
& \mathrm{M}^{*}=\mathrm{f}\left(\mathrm{U}, \mathrm{E}, \mathrm{GDP}, \mathrm{I}, \mathrm{Mor}^{*}, \mathrm{I}\right) \\
& \text { Mor }=f(P, H S B, U, E, M) \\
& \mathrm{I}=\mathrm{f}(\mathrm{HSB}, \mathrm{Mor}, \mathrm{M}, \mathrm{U}, \mathrm{E}, \mathrm{GDP}, \mathrm{HI})
\end{aligned}
$$

Where $M$ denotes murder; $M^{*}$ is murder rate, unemployment; GDP, Gross Domestic Product per capita; I, self-reported illness; Mor. Mortality; P, poverty; HSB, health care seeking behaviour; E, exchange rate, and $\mathrm{HI}$ represents health insurance coverage.

In addition to the aforementioned hypotheses, this paper will model mortality, exchange rate and murder, using available data.

\section{Materials and Methods}

The current work is a secondary data analysis. The data were derived from various Jamaica Government Publications including The Jamaica Survey of Living Conditions (JSLC) [19]; Economic and Social Survey of Jamaica (ESSJ) [20]; Statistical Digest [21] and the Demographic Statistics [22], and the Statistical Department of the Jamaica Constabulary Force (JCF). The period for this work is from 1989 to 2009.

The JSLC is jointly conducted by the Planning Institute of Jamaica (PIOJ) and the Statistical Institute of Jamaica (STATIN) [19]. The JSLC is a nationally representative cross-sectional descriptive survey which uses stratified random sampling and comprised data on households' characteristics, health, education, expenditure, social programmes, and other information. A standardized questionnaire, modeled from the World Bank's Living Standards Measurement Study (LSMS) household survey [23] was used to collect the data. There are some modifications to the LSMS, as JSLC is more focused on policy impacts.

The JSLC used a two-stage stratified random sampling design where there was a Primary Sampling Unit (PSU) and a selection of dwellings from the primary units. The PSU is an Enumeration District (ED) which constituted of a minimum of 100 dwellings in rural areas and 150 in urban areas. An ED is an independent geographic unit that shares a common boundary. This means that the country was grouped into strata of equal size based on dwellings. Based on the JSLC, the PSU is a listing of all the dwellings and this was used as the sampling framework from which a master sample of dwelling was compiled [19]. According to the JSLC [19], the sample was weighted to reflect the population of the nation. The households in the JSLC were interviewed between three to four years, after which a new representative sample was drawn. In this study, data were used aggregate to the parish level, which means that analysis can be made across periods (or over time).

The Economic and Social Survey of Jamaica (ESSJ) is a publication of the PIOJ which collates information on social and economic indicators of Jamaica. Data on unemployment rate in Jamaica were collated from the aforementioned publication for 1989 to 2009 [20].

The annual exchange rate of the Jamaican dollar to the United States dollar was collected from the Bank of Jamaica (BoJ) publication [21] and the Gross Domestic Product (GDP) information was determined 


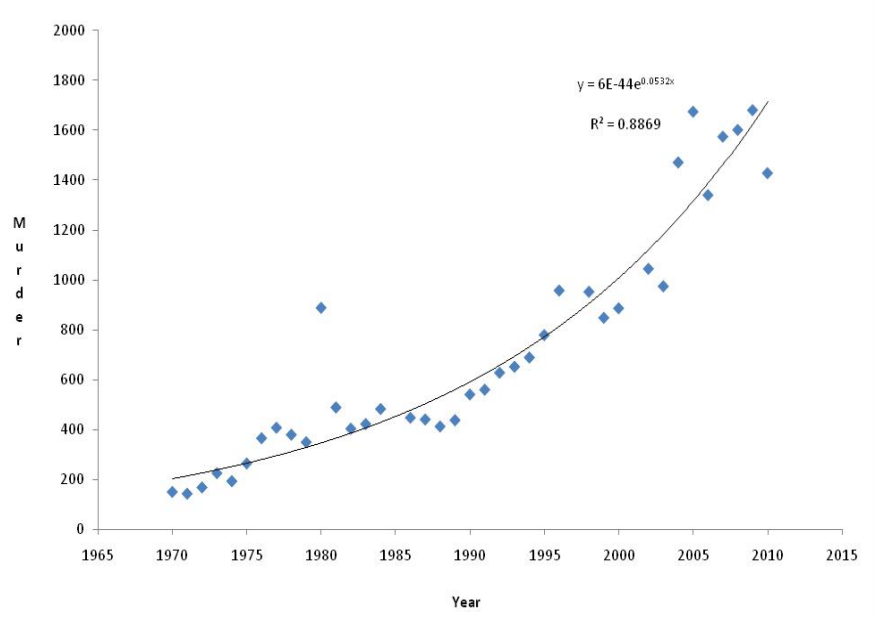

Figure1: Annual number of Murder, 1970-2010.

from the International Monetary Fund's World Economic Outlook [24]. Data on murder were obtained from Statistical Department of the Jamaica Constabulary Force (JCF) for the period 1970-2010, while the others were for the period 1989-2010.

\section{Statistical analyses}

Data were entered and stored into Microsoft Excel and Statistical Packages for the Social Sciences (SPSS) for Window, Version 21.0 (SPSS Inc; Chicago, IL, USA), which were both used to analyze the data. Pearson's Product Moment Correlation was used to assess the bivariate correlation between particular macroeconomic and other variables. Scatter diagrams and best fit models were used on the data. Ordinary least square (OLS) regression analyses were used to establish the model for 1) mortality and 2) murder. Ordinary least square regressions were utilized to analyze the possible explanatory variables. A p-value of $10 \%$ was chosen to indicate statistical significance. The variables that were entered into the model were significant in the bivariate correlation (Pearson's Product Moment Correlation). In any instance where collinearity existed $(r>0.7)$; the variables were entered independently into the model to determine as to which of those should be retained during the final model construction. The final decision on whether or not to retain the variables was based on the variables' contribution to the predictive power of the model and its goodness of fit. Each scatter plot was modeled by a linear, power, exponential or polynomial best fit function based on the data, with the aid of Excel.

\section{Variables used}

Health indices: For this paper, this concept is measured using illness rate (or self-reported illness), health-care seeking behavior (or health care utilization), health insurance coverage, health insurance utilization, and mortality.

Illness rate is a percentage of people in the population who reported having an illness in the survey week. Illness is an indicator of poor ('bad') health as only since 2007 the JSLC began collecting data on self-rated health status. Prior to that year, data on illness was collected, which was used to plan for the health of the populace.

Health-care seeking behavior (or health care utilization). This variable came from the question "Has a doctor, nurse, pharmacist, midwife, healer or any other health practitioner been visited?" with the option (yes or no). This was dummied as $1=$ reporting a doctor's visit and $0=$ otherwise. Total expenditure was used as a proxy measure of income.

Health Insurance Coverage: This is a binary measure, in which 1 denotes self-reported ownership of private or public health insurance coverage and 0 is otherwise.

Murder denotes the number of people unlawfully killed (a crime causing death without a lawful excuse) within a particular geopolitical zone (excluding police killings or homicides).

Murder rate is the total number of people unlawfully killed divided by the mean population times 100,000

Mortality means the total number of deaths occurred within the population for a particular period, which is usually at the end of a calendar year.

Mortality rate is the total number of death divided by the mean population times 100,000 .

\section{Macroeconomic indicators}

These indicators are inflation rate, poverty rate, unemployment rates and Gross Domestic Product (GDP) per capita.

The exchange rate (or Jamaican exchange rate) is the number of Jamaican dollars needed to purchase one United States' dollar (US\$1).

Inflation rate: The annual percentage movement in price index.

Unemployment rate: This is the percentage of people who are seeking a job; but who have not been able to get one.

Poverty rate: For this study, poverty is viewed from an absolute perspective. The Planning Institute of Jamaica (PIOJ) employs an absolute approach in the measurement of poverty. Poverty rate is measured by way of 1) annual survey of living conditions, 2) components in food basket and a menu which is priced by the Ministry of Health and 3) pricing the items in the basket which is done by the Statistical Institute of Jamaica (STATIN). The menu is based on particular nutritional requirements for a family of five.

\section{Results}

Figure 1 shows murders from 1970-2010, with a best fit line. Murders for the period is best fitted with an exponential function (Eqn. [4]):

Murder $=6 \times 10^{-44} \cdot \mathrm{e}^{0.0532 \mathrm{x}}$

Where $\mathrm{x}$ denotes the year, and Eqn [1] has an explanatory power of $89 \%$.

The mean murders for four decades were depicted in Figure 2. They are best fitted by an exponential function.

Murder rate $=20.663 \mathrm{e}^{0.0524 \mathrm{x}}$

Where $\mathrm{x}$ denotes the year, and Eqn [4.2] has an explanatory power of $88.5 \%$.

Figure 3 presents the mortality of Jamaicans from 1989 to 2009 and its best fitted by a 5 -degree polynomial function.

The correlation between mortality and murder is a curvilinear one (Figure 4, fitted by a 5 -degree polynomial curve).

Murder as a percentage of mortality has been increasing by geometric progressions since 1989 (Figure 5). 
Citation: Bournev PA, Mills M, Campbell-Smith J, Sharpe-Pryce C, Francis C, et al. (2014) The Influence of Macroeconomic Variables on Health Indices, Murder and Mortality: A Case of Jamaica. J Gen Pract 2: 145. doi: 10.4172/2329-9126.1000145

Page 4 of 11

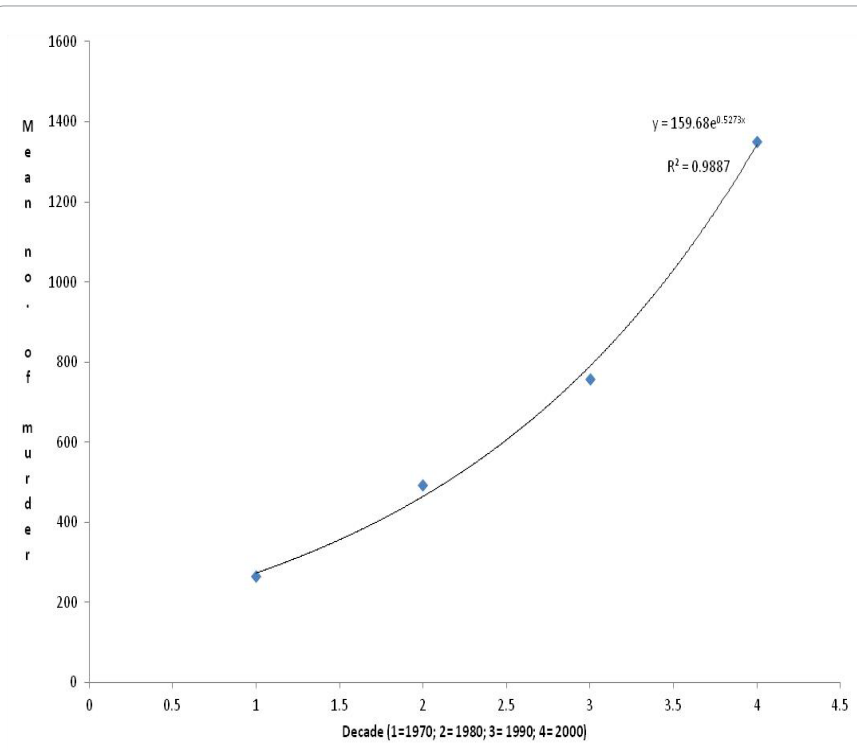

Figure 2: Mean number of murder for each decade, 1970 to 2000

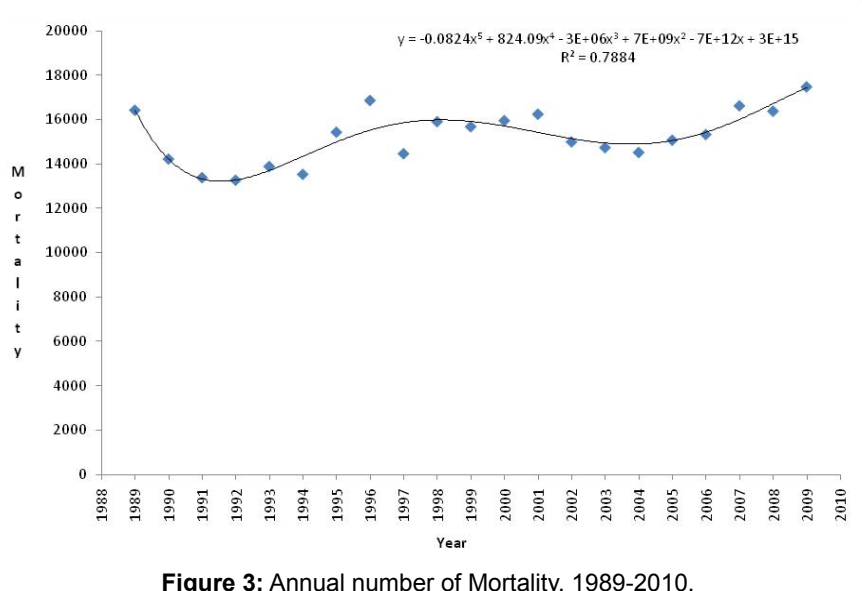

Figure 3: Annual number of Mortality, 1989-2010.

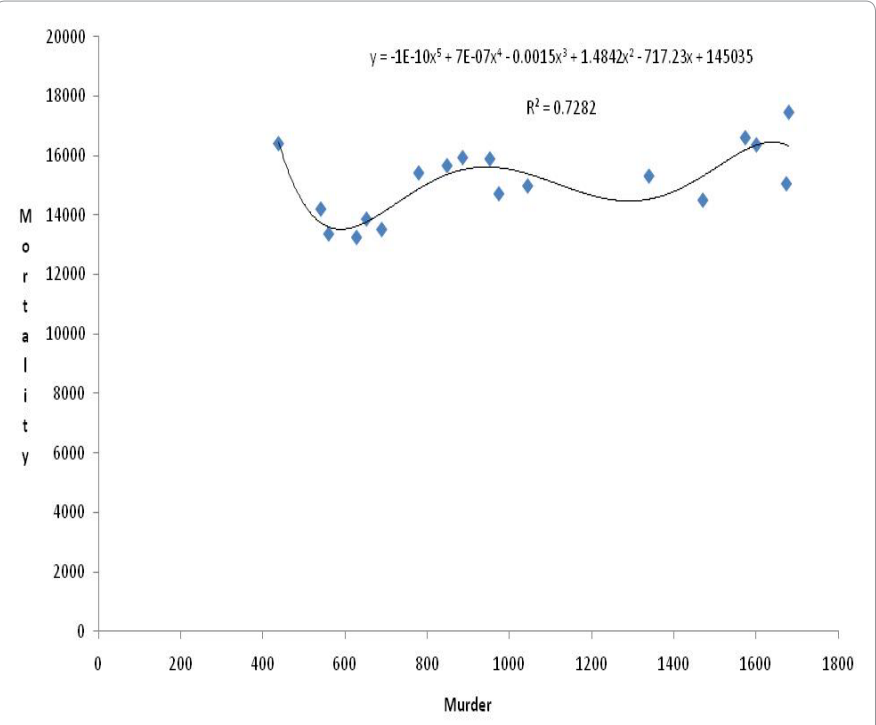

Figure 4: Annual number of Mortality and murder, 1989-2010.
Figure 6 shows that during economic recession, murder increases and during economic growth it declines.

Annual exchange rate has been increasing by arithmetic progression since 1989 (Figure 7).

Poverty as a function of murder is a hyperbolic function (Figure 8)

Murder $=17587 \mathrm{x}^{-0.971}$

Where $\mathrm{x}$ denotes the prevalence of poverty rate and the function has $70.1 \%$ predictability.

Table 1 contains statistics on selected macroeconomic indicators, health and mortality.

Table 2 detailed the bivariate correlation between selected macroeconomic indicators, health and mortality. A strong positive correlation existed between 1) log murder and exchange rate $\left(r_{s}=0.950\right.$,

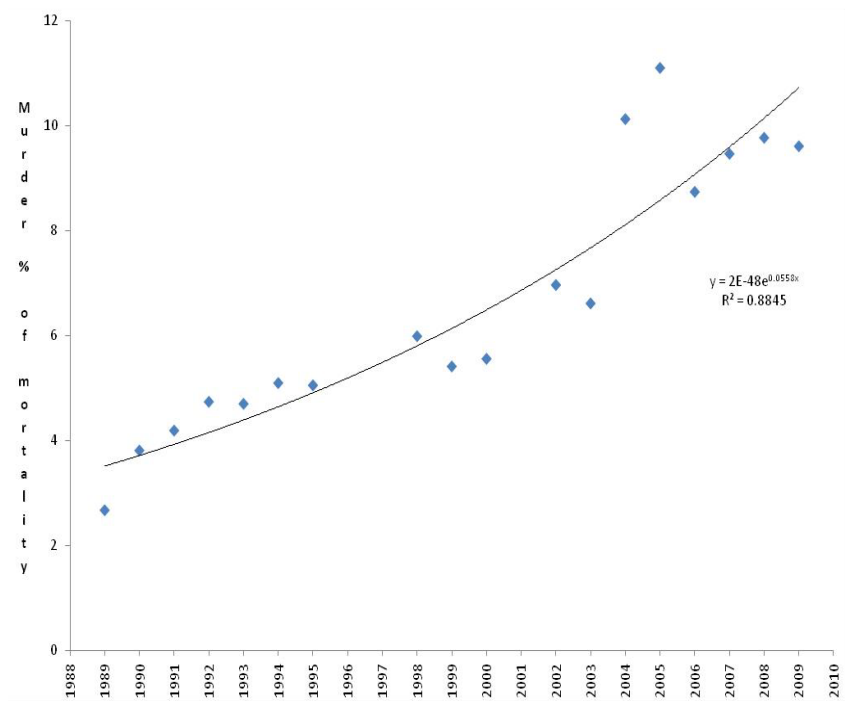

Figure 5: Annual number of Murder as a percentage of Annual number of mortality, 1989-2010.

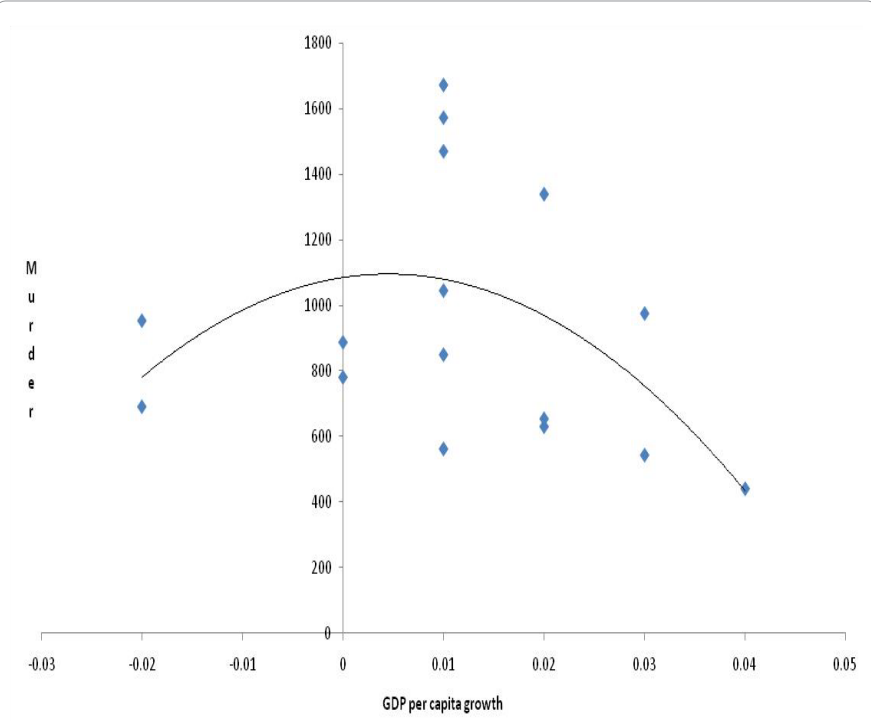

Figure 6: Annual number of Murder and GDP per capita growth0. 


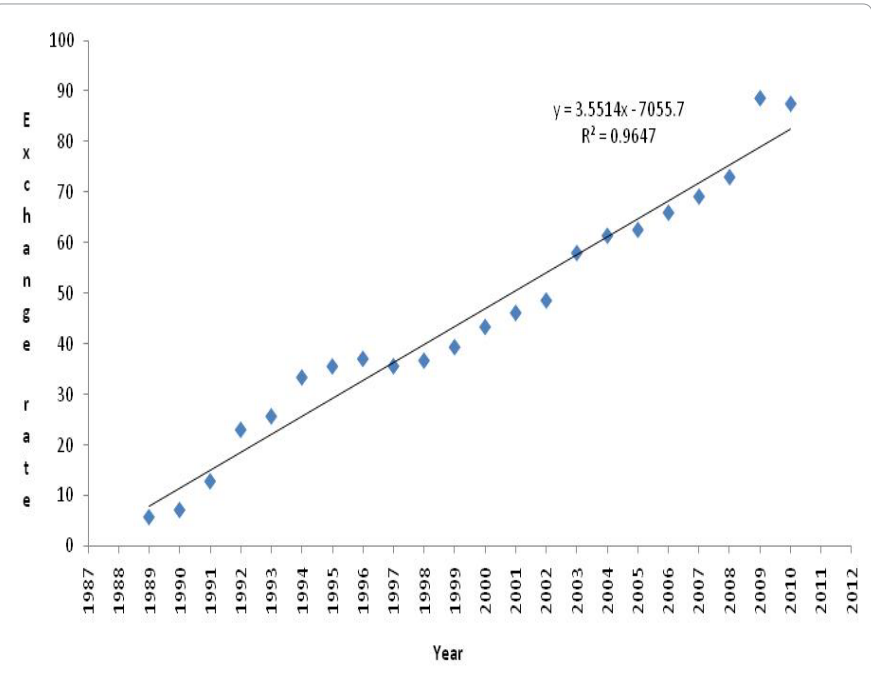

Figure 7: Annual Exchange rate.

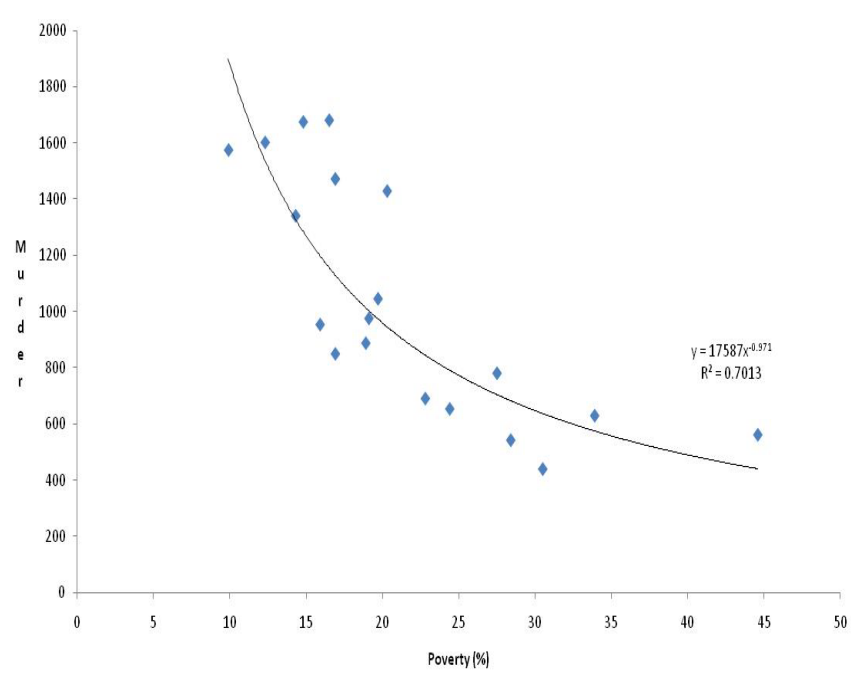

Figure 8: Annual number of Murder and prevalence of poverty (in \%).

$\mathrm{P}=0.0001)$; and 2) log murder and log health insurance coverage $\left(r_{s}=0.960, P=0.0001\right)$.

Three variables emerged as statistically significant factors of log mortality - log poverty, health care utilization, and log unemployment. The factors account for $73.5 \%$ of the variability in log mortality (Table 3). A positive correlation existed between 1) log mortality and health care utilization and 2) log mortality and log unemployment. Using the beta weighs, health care utilization has the most influence on mortality followed by poverty (Table 3).

Of the variables entered into the OLS (log murder), two emerged as statistically significant factors-log unemployment and exchange rate. The two factors account for $95.9 \%$ of the variability in log murder, with exchange rating being the most influential factor (Table 4 ).

Log murder $=\mathrm{f}($ Exchange rate, $\mathrm{U})$

Eqn [6.1]

Murder $=453.06 \mathrm{e}^{0.0162 x}$

Eqn [6.2]

Where $\mathrm{x}$ represents the exchange rate and $90.2 \%$ explanatory power can be explained by Eqn [6.2].
Of the variables entered into the OLS (murder rate), two emerged as statistically significant factors - log unemployment and exchange rate. The two factors account for $91.4 \%$ of the variability in murder rate, with exchange rating being the most influential factor (Table 5).

Murder rate $=\mathrm{f}($ Exchange rate, $\mathrm{U})$

Eqn [6.3]

Five factors emerged as significant explanations of ill-health health care utilization, log mortality, log murder, log unemployment and exchange rate. Using the beta weighs the exchange rate accounts for most of the explanations. Almost $94 \%$ of ill-health (or illness rate) can be explained by the five factors (Table 6).

\section{Discussion}

The current findings revealed that 1) the exchange rate is a strong correlated with murder, 2) health insurance coverage is positively related with log murder, 3) unemployment is directly correlated with log murder, 4) unemployment is positively associated with log mortality, 5) mortality is directly related with health care utilization, 6) an inverse relationship between $\log$ murder and $\log$ poverty and 7) during an economic recession, murder increases. Over the last 2 decades (19892010), in 2004 murders increased by $51 \%$ compared to 2003 which was the greatest increased in the period. During the period, unemployed increased by $20.6 \%$, GDP per capita growth declined by $66.7 \%$ and the exchange rate increased by $5.9 \%$, while poverty fell by $11.5 \%$. According to the Planning Institute of Jamaica, "Real Gross Domestic Product (GDP) for Agriculture, Forestry and Fishing in 2004 declined by 10.4 per cent compared to 2003" [20], and this was attributable to Hurricane Charley and Ivan in August and September respectively.

Findings from this study revealed that during the economic recession of the mid-to-late 1990s (1994-1998, excluding 1995), the average number of murders was 901 Jamaicans compared to 596 during the early 1990s (1990-1993). It follows that during the recession, murders increased by $51.2 \%$ compared to the early non-recession years. In the recession years, unemployment, illness, poverty and inflation were lower compared with the non-recession period of the early 1990s. In fact, during the recession, unemployment declined by $14.5 \%$, illness by $23.4 \%$, inflation by $67 \%$, GDP per capita by $200 \%$ and poverty by $33.4 \%$ compared with the non-recession period of the early 1990 s. Only two variables increased during the economic recessions, exchange rate (by $113.5 \%$ ) and murders (by $51.2 \%$ ). The present work shows that poverty declined at a time when murder increased, during an economic downturn.

Empirical evidence has established that crime and violence are correlated with poverty and social inequality [6,25-28]. When the issue of the crime problem is discussed, it is frequently within the context of urban and poor centres [25]. Some scholars have gone as far as to state that "The supply of offences is substantially an economic phenomenon" [29]. This suggests that crime is positively correlated with socio-economic deprivation. It may appear to be common sense that crime emerged out of material deprivation, and this perspective is sometimes presented as though they were results from academic research. This study found that poverty was strongly correlated with mortality and weakly related with crime. However, this work was contrary to the literature as a negative relationship appears between 1) poverty and mortality and 2) poverty and murder. Furthermore, the findings highlighted that during economic recession, murder increases and it declines in periods of economic expansion.

There is difficulty in trying to explain increases in mortality during an economic expansion. A study conducted in the United States found 
Citation: Bournev PA, Mills M, Campbell-Smith J, Sharpe-Pryce C, Francis C, et al. (2014) The Influence of Macroeconomic Variables on Health Indices, Murder and Mortality: A Case of Jamaica. J Gen Pract 2: 145. doi: 10.4172/2329-9126.1000145

Page 6 of 11

\begin{tabular}{|c|c|c|c|c|c|c|c|c|c|c|c|}
\hline Year & Unemployment & IIIness & HSB & Poverty & Inflation & Exchange rate & GDP per capita & Mortality & HI & Murder & Murder rate \\
\hline 1989 & 18.0 & 16.8 & 54.6 & 30.5 & 17.2 & 5.77 & 0.04 & 16414 & 8.2 & 439 & 18.48 \\
\hline 1990 & 15.3 & 18.3 & 38.6 & 28.4 & 29.8 & 7.18 & 0.03 & 14213 & 9 & 542 & 22.56 \\
\hline 1991 & 15.3 & 13.7 & 47.7 & 44.6 & 80.2 & 12.85 & 0.01 & 13376 & 8.6 & 561 & 23.13 \\
\hline 1992 & 9.4 & 10.6 & 50.9 & 33.9 & 40.2 & 23.01 & 0.02 & 13262 & 9 & 629 & 25.69 \\
\hline 1993 & 9.5 & 12.0 & 51.8 & 24.4 & 30.1 & 25.68 & 0.02 & 13878 & 10.1 & 653 & 26.82 \\
\hline 1994 & 10.9 & 12.9 & 51.4 & 22.8 & 26.8 & 33.35 & -0.02 & 13527 & 8.8 & 690 & 28.06 \\
\hline 1995 & 9.6 & 9.8 & 58.9 & 27.5 & 25.6 & 35.54 & 0 & 15426 & 9.7 & 780 & 31.35 \\
\hline 1996 & 10.8 & 10.7 & 54.9 & 26.1 & 15.8 & 37.02 & -0.02 & 16854 & 9.8 & 925 & 36.77 \\
\hline 1997 & 10.6 & 9.7 & 59.6 & 19.9 & 9.2 & 35.58 & -0.02 & 14458 & 12.6 & 1037 & 40.82 \\
\hline 1998 & 10.0 & 8.8 & 60.8 & 15.9 & 7.9 & 36.68 & -0.02 & 15901 & 12.1 & 953 & 37.17 \\
\hline 1999 & 10.0 & 10.1 & 68.4 & 16.9 & 6.8 & 39.33 & 0.01 & 15672 & 12.1 & 849 & 32.88 \\
\hline 2000 & 10.2 & 14.2 & 60.7 & 18.9 & 6.1 & 43.32 & 0 & 15945 & 14 & 887 & 34.26 \\
\hline 2001 & 10.3 & 13.4 & 63.5 & 16.9 & 8.8 & 46.09 & 0.01 & 16239 & 13.9 & 1191 & 45.74 \\
\hline 2002 & 10.6 & 12.6 & 64.1 & 19.7 & 7.2 & 48.54 & 0.01 & 14989 & 13.5 & 1045 & 39.96 \\
\hline 2003 & 9.7 & 12.51 & 58.6 & 19.1 & 13.8 & 57.93 & 0.03 & 14729 & & 975 & 37.13 \\
\hline 2004 & 11.7 & 11.4 & 65.1 & 16.9 & 13.7 & 61.34 & 0.01 & 14513 & 19.2 & 1471 & 55.76 \\
\hline 2005 & 11.2 & 12.51 & 58.6 & 14.8 & 12.6 & 62.5 & 0.01 & 15065 & & 1674 & 63.16 \\
\hline 2006 & 10.3 & 12.2 & 70.0 & 14.3 & 5.7 & 65.88 & 0.02 & 15321 & 18.4 & 1340 & 50.32 \\
\hline 2007 & 9.8 & 15.5 & 66.0 & 9.9 & 16.8 & 69.06 & 0.01 & 16614 & 21.2 & 1574 & 58.82 \\
\hline 2008 & 10.6 & 8.7 & 72.9 & 12.3 & 16.8 & 72.92 & -0.8 & 16371 & 21.1 & 1601 & 59.58 \\
\hline 2009 & 11.4 & 10.6 & 77.1 & 16.5 & 10.2 & 88.49 & -3.1 & 17467 & 19.8 & 1680 & 62.32 \\
\hline 2010 & 12.9 & & & 20.3 & 13.0 & 87.38 & -1.4 & 17007 & & 1428 & 52.98 \\
\hline
\end{tabular}

Table 1: Selected macroeconomic indicators, health and mortality statistics.

$\mathrm{HI}$ denotes health insurance coverage, HSB represents health seeking behaviour (or health care utilization) and CDR indicates crude death rate.

\begin{tabular}{|c|c|c|c|c|c|c|c|c|c|c|c|}
\hline & & $\begin{array}{c}\text { Ln } \\
\text { Mortality }\end{array}$ & $\begin{array}{c}\text { Ln } \\
\text { Murder }\end{array}$ & $\begin{array}{l}\text { Log } \\
\text { Insurance }\end{array}$ & $\begin{array}{c}\text { GDP } \\
\text { Per capita }\end{array}$ & $\begin{array}{c}\text { Log } \\
\text { Unemployment }\end{array}$ & $\begin{array}{c}\text { Log } \\
\text { Inflation }\end{array}$ & $\begin{array}{l}\text { Log } \\
\text { Poverty }\end{array}$ & illness & $\begin{array}{c}\text { Health care } \\
\text { utilization }\end{array}$ & $\begin{array}{l}\text { Exchange } \\
\text { rate }\end{array}$ \\
\hline \multirow{3}{*}{ Ln Mortality } & Pearson Correlation & 1 & & & & & & & & & \\
\hline & Sig. (2-tailed) & & & & & & & & & & \\
\hline & $\mathrm{N}$ & 21 & & & & & & & & & \\
\hline \multirow{3}{*}{ Ln Murder } & Pearson Correlation & $.515^{\star}$ & 1 & & & & & & & & \\
\hline & Sig. (2-tailed) & .029 & & & & & & & & & \\
\hline & $\mathrm{N}$ & 18 & 19 & & & & & & & & \\
\hline \multirow{3}{*}{$\begin{array}{l}\text { Log Health } \\
\text { Insurance }\end{array}$} & Pearson Correlation & .382 & $.960^{* *}$ & 1 & & & & & & & \\
\hline & Sig. (2-tailed) & .130 & .0001 & & & & & & & & \\
\hline & $\mathrm{N}$ & 17 & 14 & 17 & & & & & & & \\
\hline \multirow{3}{*}{ GDP per capita } & Pearson Correlation & -.100 & -.248 & -.048 & 1 & & & & & & \\
\hline & Sig. (2-tailed) & .684 & .354 & .856 & & & & & & & \\
\hline & $\mathrm{N}$ & 19 & 16 & 17 & 19 & & & & & & \\
\hline \multirow{3}{*}{$\begin{array}{c}\text { Log } \\
\text { Unemployment }\end{array}$} & Pearson Correlation & -.055 & -.456 & -.418 & .381 & 1 & & & & & \\
\hline & Sig. (2-tailed) & .814 & .057 & .095 & .108 & & & & & & \\
\hline & $\mathrm{N}$ & 21 & 18 & 17 & 19 & 21 & & & & & \\
\hline \multirow{3}{*}{ Log Inflation } & Pearson Correlation & $-.547^{\star}$ & $-.861^{* *}$ & $-.878^{* *}$ & .149 & $.473^{*}$ & 1 & & & & \\
\hline & Sig. (2-tailed) & .010 & .0001 & .0001 & .544 & .030 & & & & & \\
\hline & $\mathrm{N}$ & 21 & 18 & 17 & 19 & 21 & 21 & & & & \\
\hline \multirow{3}{*}{ Log Poverty } & Pearson Correlation & $-.547^{*}$ & $-.861^{* *}$ & $-.878^{* *}$ & .149 & $.473^{*}$ & $1.0001^{* *}$ & 1 & & & \\
\hline & Sig. (2-tailed) & .010 & .00011 & .0001 & .544 & .030 & .0001 & & & & \\
\hline & $\mathrm{N}$ & 21 & 18 & 17 & 19 & 21 & 21 & 21 & & & \\
\hline \multirow{3}{*}{ illness } & Pearson Correlation & -.093 & -.411 & -.078 & $.589^{* *}$ & $.621^{* *}$ & .215 & .215 & 1 & & \\
\hline & Sig. (2-tailed) & .689 & .090 & .766 & .008 & .003 & .350 & .350 & & & \\
\hline & $\mathrm{N}$ & 21 & 18 & 17 & 19 & 21 & 21 & 21 & 21 & & \\
\hline \multirow{3}{*}{$\begin{array}{l}\text { Health care } \\
\text { utilization }\end{array}$} & Pearson Correlation & $.654^{* *}$ & $.792^{* *}$ & $.790^{* *}$ & -.151 & -.412 & $-.753^{* *}$ & $-.753^{* *}$ & $-.494^{*}$ & 1 & \\
\hline & Sig. (2-tailed) & .001 & .0001 & .0001 & .537 & .063 & .0001 & .0001 & .023 & & \\
\hline & $\mathrm{N}$ & 21 & 18 & 17 & 19 & 21 & 21 & 21 & 21 & 21 & \\
\hline \multirow{3}{*}{ Exchange Rate } & Pearson Correlation & $.507^{*}$ & $.950^{* *}$ & $.922^{* *}$ & -.144 & $-.484^{*}$ & $-.818^{* *}$ & $-.818^{* *}$ & -.380 & $.848^{* *}$ & 1 \\
\hline & Sig. (2-tailed) & .019 & .0001 & .0001 & .558 & .026 & .0001 & .0001 & .089 & .0001 & \\
\hline & $\mathrm{N}$ & 21 & 19 & 17 & 19 & 21 & 21 & 21 & 21 & 21 & 22 \\
\hline
\end{tabular}

*. Correlation is significant at the 0.05 level (2-tailed).

Table 2: Bivariate correlation of selected macroeconomic indicators, health and mortality 
Citation: Bournev PA, Mills M, Campbell-Smith J, Sharpe-Pryce C, Francis C, et al. (2014) The Influence of Macroeconomic Variables on Health Indices, Murder and Mortality: A Case of Jamaica. J Gen Pract 2: 145. doi: 10.4172/2329-9126.1000145

Page 7 of 11

\begin{tabular}{|l|l|l|l|l|l|}
\hline & B Coefficients & Std. Error & Beta & P value & Cl (95\%) \\
\hline Constant & 10.110 & 0.885 & & 0.0001 & $8.182-12.038$ \\
\hline Log poverty & -0.143 & 0.065 & -0.685 & 0.048 & $-0.285--0.002$ \\
\hline $\begin{array}{l}\text { Health care } \\
\text { utilization }\end{array}$ & 0.006 & 0.002 & 0.769 & 0.025 & $0.001-0.012$ \\
\hline $\begin{array}{l}\text { Log } \\
\text { Unemployment }\end{array}$ & 0.167 & 0.075 & 0.389 & 0.047 & $0.002-0.331$ \\
\hline Exchange rate & 0.001 & 0.002 & 0.182 & 0.793 & $-0.004-0.006$ \\
\hline Log Murder & -0.127 & 0.119 & -0.682 & 0.308 & $-0.385-0.132$ \\
\hline $\begin{array}{l}\mathrm{R}^{2}=0.735 \\
\text { Adjusted } \mathrm{R}^{2}=0.625\end{array}$ & & & & \\
\hline F statistic [5,12]=6.659, $\mathrm{P}=0.003$ & & & & \\
\hline $\mathrm{N}=17$ & & & & \\
\hline Durbin-Watson=2.6 & & & & & \\
\hline
\end{tabular}

Table 3: OLS of log mortality and selected macroeconomic and health indicators Dependent variable: Log Annual number of mortality.

\begin{tabular}{|l|l|l|l|l|l|}
\hline & B Coefficients & Std. Error & Beta & $\begin{array}{l}\text { P } \\
\text { value }\end{array}$ & Cl (95\%) \\
\hline Constant & 7.345 & 7.297 & & 0.344 & $-9.482-24.173$ \\
\hline $\begin{array}{l}\text { Log } \\
\text { unemployment }\end{array}$ & 0.544 & 0.256 & 0.267 & 0.067 & $-0.048-1.135$ \\
\hline Exchange rate & 0.020 & 0.004 & 1.019 & 0.001 & $0.011-0.029$ \\
\hline GDP per capita & -0.472 & 2.221 & -0.019 & 0.837 & $-5.593-4.649$ \\
\hline Log inflation & -0.272 & 0.209 & -0.256 & 0.230 & $-0.755-0.211$ \\
\hline Log mortality & -0.007 & 0.757 & -0.001 & 0.993 & $-1.753-1.739$ \\
\hline Log illness & -0.449 & 0.274 & -0.218 & 0.140 & $-1.082-0.183$ \\
\hline $\begin{array}{l}\mathrm{R}^{2}=0.959 \\
\text { Adjusted } \mathrm{R}^{2}=0.923\end{array}$ & & & & \\
\hline F statistic $[7,8]=26.844, \mathrm{P}=0.0001$ & & & & \\
\hline $\mathrm{N}=15$ & & & & & \\
\hline Durbin-Watson=2.4 & & &
\end{tabular}

Table 4: OLS of log murder and selected macroeconomic and health indicators Dependent variable: Log Annual number of murder.

that mortality increases in economic expansion [30], declines in a recession as is the case in some developed nations [31] and is a cyclical phenomenon [32]. Using other macroeconomic indicators such as inflation, poverty and the exchange rate, in this study it was revealed that there is direct association between the exchange rate and murder as well as mortality. It can be deduced from the aforementioned result that crimes increase geometrically in times of increased exchange rate. Other macroeconomic indicators that refute the poverty and crime phenomenon were 1) the negative statistical correlation that emerged between the exchange rate and inflation, and 2) exchange rate and poverty. With the inverse relationship between the exchange rate and poverty as well as between the exchange rate and inflation, mortalities and murder in Jamaica are not in keeping with the common sense notion of material deprivation.

It can be extrapolated from the literature that poverty explains rise in crime, which is refuted by this work. What is poverty associated with in Jamaica? This paper found that poverty is directly related to unemployment and illness, and inversely associated with health care utilization, exchange rate and health insurance coverage as well as murder and mortality. In addition to the aforementioned results, a direct relationship emerged between unemployment and mortality, and unemployment was not statistical related with murders in Jamaica. Unemployment, however, was positively related with illness. These findings highlight that common sense argument of material deprivation should not be ascribed to murders; but that it has something to do with inflation and unemployment. Then, what explains high level of crime and violence to which Jamaicans have become so accustomed since the 1980s [10]?

According to Harriott [2] there is a shift in traditional pattern of criminal activities. Marlyn Jones [33] opined that the rate of crime and victimization against women has been since 1990 to 2001, particularly sexual assault, rape and murders. When Harriott, Headley, Jones and other scholars identified in this paper wrote on the crime issue in the Caribbean, particularly Jamaica and Trinidad and Tobago, it was at the start of decade of 2000. At the end of the decade of 2000 (2010), the rate of growth for murders in Jamaica was $94 \%$ over the decade of the 1990s compared to the $43 \%$ increase that was observed in the 1990 s over the 1980s. The shifts in murders are attributable to the continuous rise in the exchange rate, unemployment and the economic recessions. Simply put, murders are as a result of general economic hardship and not merely the inability to spend a certain amount of money per day (poverty). Such a reality implies that murders are economic and survival phenomena, which should not be limited to poverty. Although poverty applies to only a few in society, the high cost of living affects the entire nation.

Examining the murder statistics within the context of the macroeconomic indicators has provided insights into the justifications of the rise in crime, particularly murders. The main findings of current study provide a platform of understanding the shifts in murders - one, health insurance coverage, two, and three, health care utilization. A positive correlation emerged between the 1) exchange rate and health insurance, and 2) exchange rate and health care seeking behaviour. With the negative association between 1) poverty and health insurance and 2) poverty and health care utilization, the findings suggest that affluent people are engaged in criminal activities in order to capitalize on the profits from increased value of the US dollars. According to Harriott, the traditional criminal activities are changing, and material deprivation is not responsible for the high levels of murder [17]. However, economic deprivation is resulting in premature deaths that accounts for the rise in mortality. According to the World Health Organization (WHO) [34] $80 \%$ of people with chronic illnesses were in developing countries and that $65-70 \%$ of them were unable to afford medication. It noted further that $60 \%$ of global mortality is caused by chronic illness [34]. This suggests that the lack of money (including unemployment) impedes 'good' health that is confirmed by this work.

Poverty is attributable to unemployment, lack of resources, limited opportunities, availability of choices (including health care utilization, health insurance coverage) and ill-health, which could account for people postulating that it affect murder. There is a clear distinction between mortality and murder, and the aforementioned issues account for increased mortality and not murder. The economic hardship that people face because of an economic recession accounts for the increased murder, and not the poverty. When compare 2007 with 2006 , poverty declined by $30.8 \%$, unemployment fell by $4.9 \%$, GDP per capita growth dropped by $50 \%$, and inflation increased by $194.7 \%$, with murder increased by $17.5 \%$. Again, poverty is not accounting for the increased murders; it is the difficult time expressed through macroeconomic indicators like inflation and GDP. This is concretized by a study conducted by Powell and colleagues in 2007 which found that 69 of every 100 Jamaican indicated that their present economic situation [at the time of the survey] was at most average, 62 of every 100 people stated that their salary was unable to cover basic needs, and 43 out of every 100 mentioned that they were very concerned about the likelihood of being unemployed in the upcoming 12 months. Over the four decades (1970-1979, 1980-1989, 1990-1999, 2000-2010), murders 
Citation: Bournev PA, Mills M, Campbell-Smith J, Sharpe-Pryce C, Francis C, et al. (2014) The Influence of Macroeconomic Variables on Health Indices, Murder and Mortality: A Case of Jamaica. J Gen Pract 2: 145. doi: 10.4172/2329-9126.1000145

Page 8 of 11

\begin{tabular}{|c|c|c|c|c|c|c|}
\hline & \multicolumn{2}{|c|}{ Unstandardized Coefficients } & \multirow{2}{*}{$\begin{array}{l}\text { Standardized Coefficients } \\
\text { Beta }\end{array}$} & \multirow{2}{*}{$\mathbf{t}$} & \multirow{2}{*}{$P$ value } & \multirow{2}{*}{$\begin{array}{l}\text { 95.0\% Confidence Interval } \\
\text { Lower - Upper }\end{array}$} \\
\hline & B & Std. Error & & & & \\
\hline Constant & 37.556 & 33.518 & & 1.120 & 0.283 & $-34.856-109.967$ \\
\hline In Unemployment Rate & 19.970 & 9.769 & 0.247 & 2.044 & 0.062 & $-1.134-41.074$ \\
\hline GDP & -0.368 & 0.942 & -0.053 & -0.391 & 0.702 & $-2.403-1.667$ \\
\hline Exchange Rate & 0.466 & 0.102 & 0.734 & 4.571 & 0.001 & $0.246-0.686$ \\
\hline InIIIness & -5.342 & 9.204 & -0.076 & -0.580 & 0.572 & $-25.226-14.542$ \\
\hline InInflation Rate & 2.433 & 2.407 & 0.120 & 1.011 & 0.331 & $-2.767-7.633$ \\
\hline Mortality Rate & -0.020 & 0.033 & -0.060 & -0.618 & 0.547 & $-0.091-0.051$ \\
\hline \multicolumn{7}{|l|}{$\begin{array}{l}R^{2}=0.914 \\
\text { Adjusted } R^{2}=0.867\end{array}$} \\
\hline \multicolumn{7}{|c|}{$F$ statistic $[7,13]=19.702, P=0.0001$} \\
\hline \multicolumn{7}{|c|}{$\mathrm{N}=20$} \\
\hline Durbin-Watson=1.9 & & & & & & \\
\hline
\end{tabular}

Table 5: OLS of murder rate and selected macroeconomic and health indicators.

\begin{tabular}{|c|c|c|c|c|c|}
\hline & B Coefficients & Std. Error & Beta & $P$ value & $\mathrm{Cl}(95 \%)$ \\
\hline Constant & -61.238 & 64.682 & & 0.380 & $-219.508-97.033$ \\
\hline Health care utilization & -0.409 & 0.080 & -1.346 & 0.002 & $-0.605--0.213$ \\
\hline Log mortality & 16.205 & 5.922 & 0.458 & 0.034 & $1.713-30.696$ \\
\hline Log murder & -15.771 & 5.731 & -2.246 & 0.033 & $-29.794--1.748$ \\
\hline Log unemployment & 6.945 & 2.123 & 0.532 & 0.017 & $1.751-12.140$ \\
\hline Exchange rate & 0.311 & 0.088 & 2.326 & 0.013 & $0.095-0.527$ \\
\hline GDP per capita growth & 20.703 & 27.527 & 0.126 & 0.480 & $-46.652-88.058$ \\
\hline Log health insurance & 7.940 & 5.535 & 0.941 & 0.201 & $-5.603-21.484$ \\
\hline \multicolumn{6}{|l|}{$\begin{array}{l}\mathrm{R}^{2}=0.935 \\
\text { Adjusted } \mathrm{R}^{2}=0.859\end{array}$} \\
\hline \multicolumn{6}{|c|}{ F statistic $[7,6]=12.291, P=0.004$} \\
\hline \multicolumn{6}{|c|}{$N=13$} \\
\hline Durbin-Watson = 2.1 & & & & & \\
\hline
\end{tabular}

Dependent variable: Self-reported Illness rate (in \%)

Table 6: OLS of illness rate and selected macroeconomic and health indicators.

in 2007 was the third highest in Jamaica's history during which there was a geometric progression in inflation, increases illness and severe economic downturn.

The economic decline in the Jamaica economy in 2007 over 2006 is associated with a $27 \%$ and $8.4 \%$ rise in illness and mortality, respectively. The economic downturn is shifting the prospective on traditional criminal as people seek to survive in economic hardship. The change in economic fortune and lifestyle of the non-poor Jamaicans is a justification for the increased murder, ill-health and premature mortality. The fear of misfortune explains the growth in criminal activity, murders, health care utilization, and health insurance coverage. Embedded in the findings is the rise in psychological disorders among non-poor as well as poor Jamaicans. The aforementioned perspective is embodied in the following findings: 1) an inverse relationship between poverty and health care utilization, 2) a positive correlation between illness and poverty, 3 ) a negative association between poverty and health insurance coverage, 4) an inverse association between health care utilization and illness, 5) a positive relationship between unemployment and ill-health and 6) a positive statistical relationship between unemployment and illness. The direct relationship between unemployment and illness speaks to the increased psychological illnesses that arise during job separation. Job separation means lost income, diminished opportunities, limited choices, negative self-worth and social isolation, which are likely to induce psychological disorders such as suicide ideation and various states of depression.

The positive association between unemployment and mortality and mortality and illness indicate premature deaths as people commit suicide, get heart attacks, and stroke and other stress-related illnesses that may result in death due economic disparity. The aforementioned findings are the justification behind Wilks et al. study that found the rate of dissatisfaction (very dissatisfied with life) increased by $96.2 \%$ in 2008 over 2000, and that 33 of every 100 Jamaicans aged 15-74 years old indicated being depressed, hopeless or feeling down [35]. On examining the disaggregated attempted suicide statistics in Wilks et al. work, the greatest was among people aged 35-44 years (4.7\%) followed by those 55-64 years old (3.7\%), which was greater than $2.2 \%$ for the population. Furthermore, among the aged cohorts depressed (or hopeless, feeling down), the highest prevalence was among those $35-44$ years $(38 \%)$ compared to the $33 \%$ of the population [35]. Depression was 1.7 times greater among females than males and attempted suicides was 1.5 times greater for females, indicating that economic hardship is destroying the human capital of Jamaicans, particularly females and those in the working population [35]. The economic hardship is having a twin effect on the human capital of Jamaicans, by eroding people's psychological health, increasing mortality and murder because people have greater challenges with employing healthy coping mechanisms during economic recession. Much of this discussion has been centered around economic downturn, poverty, mortality, murder, and the exchange rate, with little on 1) structural adjustment, 2) governmental policy and 3) economic and financial crisis at particular times in the history of the nations, and juxtaposing these with murder statistics. Following structural adjustments in the early 1980s, Jamaica experienced unprecedented double-digit inflation and poverty, with inflation rising to $80.2 \%$ and poverty $44.6 \%$ in 1991 . The exchange rate in 1991 over 1990 rose by $79 \%$, unemployment by $57.0 \%$, inflation by $169.1 \%$ and GDP per capita 
growth declined by $66.7 \%$ indicating an economic crisis. In the same period, the unemployment rate was $15.3 \%$ which was the highest in 2 decades (1989-2010). The crisis of the 1990s heralded massive job displacement, increased cost of survivability, high rates of psychological disorders coupled with foreclosure and business downsizing that account for the geometric progression increase in murder. Melville [36] declared that structural adjustment caused massive job displacement, and that among the consequences of the adjustment was the significant burden placed on the poor. Another group of scholars [37] concluded that the social cost of structural adjustment was devastating as it eroded the human capital, which extends beyond the poor to all peoples.

According to the International Monetary Fund (IMF), "Public debt [for Jamaica] increased substantially after a banking crisis in the mid1990s and currently stands at 128 percent of GDP, despite a program adopted in 2004 to reduce it to around 100 percent of GDP by 2009" [38]. This suggests that the economic burden of the populace was huge and the high interest rate policy accompanied by devaluation of the Jamaican dollar by the government were aiding in the closure of many businesses. The governmental policies were resulting in dissolution of business, increased bankruptcy and double-digit rate of unemployment. On Sunday, July 10, 2011, one businessman wrote that the government 1) had placed business in a "competitive straightjacket", and 2) "Once exchange controls were lifted in 1991, without any arrangements or plans to contains domestic inflation or reserves or regulations to prevent rapid depreciation of the currency, the business landscape in Jamaica radically destabilized" [39]. The depreciation of the value of the Jamaican dollar compared to other foreign currency such as the United States in addition to the high interest rates during the 1990s accounted for the geometric progression in murder outside of previous discussions on the economic and financial crisis of the 1990s.

The issue as to why murders in decade of 2000 were the highest over the four decades (1970-1979; 1980-1989; 1990-1999; 2000-2010) must be clarified in this work. The economic hardship had spilled over from the decade of the 1990s, which account for the rise in ponzi schemes. Ponzi schemes were introduced as a means to fill the void created by the formal financial institution and the governmental policies that had resulted in the erosion in quality of life of many people. A study by CaPRI [40] found $73 \%$ of investors in alternative investment schemes (AIS) indicated that they were better off investing in AISs, and that the most popular usage of the returns was for bill payment (utilities, 14\%). Then the closure of Ponzi schemes came in late 2000, which would have left many people being unable to pay their utilities and other bills. Although the schemes had created a fictitious good economy, they were alleviating the economic hardship of the period. In the decade of 2000 , the averaged annual exchange rate was J $\$ 63.95$ for US $\$ 1$, which had increased by $123.4 \%$ over the decade of the 1990 s.

Clarke succinctly added that "It is interesting that when faced with the same WTO [World Trade Organization] -promoted import duty reductions, Trinidad and Tobago tactically devalued its currency by 10 per cent and maintained its producers' competitiveness. The Jamaican Government, at the same time [during the 1990s], was witlessly revaluing the Jamaican dollar..." [39]. The high interest rate regime as well as the exchange rate was responsible for the increased production cost coupled with the destruction of domestic development. This extends to more than the non-competitiveness of exporters, the uncompetitive Jamaican dollar and 'bad debtors' to exponential rise in murders. The liberalization of the financial sector (Phase I - 1986-1988 and Phase II - 1990-1991) coupled the removal of exchange rate control which was in keeping with liberalization account for the financial crisis and the exponential rise in the inflation rate to $80.2 \%$ in 1991 [41,42]. The financial crisis was substantially felt in 1997 and during that time "Depositors withdrew their savings from what were perceived to be weak institutions, mainly indigenous with local managers, and deposited these funds with branches of foreign banks" [41], indicating the human crisis that had start to brew.

In response to the financial crisis, the government created two institutions - Financial Institutions Services Limited (FIS) and the Financial Sector Adjustment Company Limited (FINSAC) that were primarily responsible for the recovery of the failed banks and the restructuring of the financial sector [41]. The ailing financial institutions were aided by governmental intervention, many people lost savings, investments and numerous businesses went bankrupt including some banks (Century Financial Entity, Eagle Merchant Bank, Blaise Financial Entity). In examining the rationale for the failure of the financial sector, Kirkpatrick and Tennant argued that "Liberalization increases banks' opportunities to take on risk as once interest rate ceilings and credit controls are lifted, banks can finance riskier ventures in exchange for higher promised returns" [41]. The governmental intervention had included the examination of the role of the financial crisis on the murder or mortality and instituting policy to minimize increases, instead the emphasis was on the financial sector while human suffering lingers. The financial crisis which had reached its zenith in the 1997 meant that people were ailing; coupled with further devastation from the Ponzi schemes in addition to the high interest rate and an exchange rate are justification of the geometric increase in murders during the decade of the 2000 .

Not only were liberalization and governmental policies devastating businesses and hurting the exporters, the continued increases in the exchange rate as well as the high interest rates were removing the competitiveness from the productive sector and increasing unemployment. The Ponzi schemes that have defrauded people of billions of dollars worsen the human suffering in a fictitious economy. After which there was the global economic and financial crises. The economic recession in the United States in the decade of 2000 [43] had affected the Jamaican economy, particularly through remittances.

In 2010, a study by Kevin [44] found that $52 \%$ of Jamaicans who received remittances had reduced amounts since the recession in the US. Eighteen percent of remittance inflows were used for food (18\%), education (14\%), utility (19\%) and medical expenses (7\%). The Bank of Jamaica commissioned study revealed that the majority of remittances were received by unemployed Jamaicans $(24.3 \%)$ followed by self-employed people (12.1\%), students $(8.4 \%)$ and retirees $(4.4 \%)$ and that inflows were mostly from United States (62\%) [44]. The macroeconomic indicators such as inflation, poverty, exchange rate, GDP per capita during the decades of 2000 had severely deteriorated the human capital of Jamaicans so much so that increased mortality and murders were consequences of the economic climate. The economic climate [40-42,45-47] had set the stage for the murderous place that the country has become, and economy that is falsely based on pyramid-driven schemes, high interest rate, lost money, lowered remittances (or income), high unemployment and significant increases in cost of living will see rise in murder and mortality. The fact that the economic environment in Jamaica over the last decade (2000-2010) has seen double unemployment (average unemployment rate $=10.6 \%$ ), with unemployment being direct correlated with illness (or ill-health); the economic climate is both 'bad' for health and public health care expenditure. 
Murders have contributed to the destruction of the social fabric of the Jamaican society. According to Harriott [2], with respect to murders, Jamaica was ranked number one (1) in the Caribbean; and in 2005, it was the highest in the world [48]. Using a probability sample of 1,595 Jamaicans, the LAPOP 2006 survey found that 1 in every 10 respondents was a victim of crime [48], indicating that crime, violence and victimization are rampant in the society and account for a percentage of premature mortality. Statistics revealed that in 2004, $78.9 \%$ of the murders were committed against Jamaicans less than 41 years old, $48.8 \%$ less than 31 years and $30.3 \%$ at most 25 years old [20], while the life expectancy stood at 72 years [49]. Clearly, murders cannot be only seen as a social barometer indicating problems in social relationships; it is a public health issue. Although it is rarely considered as such, McDonald [50] posited that violence is a public health issue and this concurred by this research. In fact, we go further to McDonald to purport that murders contribute more to health than many of the macroeconomic indicators except the exchange rate.

The phenomenon (murder) is a public health matter, which cannot be studied only in sociology, criminology, forensic, criminal justice, legal studies, public policy, political science, history and anthropology. It also has to be studied from a health and psychological perspective with some emphasis on mental health conditions in Jamaica. Using data from the Statistical Institute of Jamaica, for 2008, murders account for $9.9 \%$ of mortality, which was among the ten leading causes of death, and it was found to be greater than hypertensive diseases as a cause of mortality [22]. Murder is an epidemic in Jamaica and continues to shorten the life expectancy of many individuals. This public health phenomenon has its roots in economic parameters, and makes the job of the police, health care practitioners and social works even more difficult as its reduction is complex and outside of their ambits.

The percentage of murders in relationship to mortality in Jamaica has been rising in geometric progression, and poverty should not be ascribed to increases in murders as there is an inverse correlation between murder and poverty. The macroeconomic indicators such as GDP per capita growth (particularly during a recession or economic downturn) and the exchange rate are explanatory for the rises in the murder rate, and greater numbers fallen below the poverty line and increase unemployment provide explanation for increases in poor health and finally mortality.

With "more than half of the goods regularly purchased by consumers [being] sensitive to changes in the exchange rate" [47], fluctuations in the Jamaican exchange rate, particularly upward movements increases the cost of living of the general populace and account for the geometric increases in murders. Hence, policy makers must, with necessity, treat the macroeconomic variables simultaneously with murder as they are twinned phenomena. This paper has policy as well as practical significance as it embrace quality of life, length of life, economic environment and human experiences. It also shows that the twinned phenomena if treated as such can have significant implications for the economic prosperity of Jamaica and the social mobility of the Jamaican people. The current findings provide an insight into an economic phenomenon that holds the key to an issue that has plague the country for some time. The exchange rate, hereafter, should be viewed as economic and social phenomena, and that instability in the exchange market will eventually lead to changes in the levels of murder as well as health among the population.

The emerging findings and knowledge gleaned from this work present a critical guide and a framework for policy practitioners to implement measure that can effectively address increases in murder and/or mortality. The current moderate decline in murders can hardly be counted as an accomplishment as there are many macroeconomic indicators that will continue to worsen and these will result in upward movements in murder. The geometric progression in murders cannot change to an arithmetic progression without fundamental changes in the economic base of the society. Governments need to institute temporary measure to alleviate the economic burden on families during economic crises as failure to do this will negatively affect the quality of the human capital in Jamaica. This will then contribute to psychological disorders rising and that could see a shift in murders to family suicides. This is admittedly a grim picture but it could no doubt become the reality. We are championing a perspective that murder should be treated as an macroeconomic phenomenon as interest rate, inflation, money supply, unemployment and exchange rate, which should be managed by the Bank of Jamaica in collaboration with the 1) Ministry of Health, 2) Ministry of Justice, and 3) Ministry of Finance.

\section{Conclusion}

In summary, murder as well as mortality is a social barometer; but it must also be treated as a public health issue. The present study established that murder and ill-health are negative correlated with each other and this offers an insight into how murder reduces the health status of those who are alive. Macroeconomic indicators such as poverty, unemployment and the exchange rate are accounting for changes in health status of the Jamaican population. The reality is health discourse cannot be void of murder as the present findings support its inclusion.

\section{Limitations of Study}

The use of secondary data poses a problem for a wider coverage of phenomenon. However, it is also a benefit was the researchers would not have been able to collect such materials. Other advantages of the current work are 1) its contribution to the empiricism, 2) the data are of a high quality as they are verified by the World Bank, and use by it to report on macroeconomic and health indicators for Jamaica, 3) a high degree of validity and reliability and 4) the use of many data points make the findings high generalizable instead of a single data point.

\section{Acknowledgment}

The authors would like to thank Assistant Commandant Desmond D. Brooks, from the Jamaican Island Special Constabulary Force (ISCF), for his comments and time in reviewing the early draft of this paper.

\section{Conflict of Interest}

The researchers have no conflict of interests to report at this time.

\section{References}

1. Powell LA, Bourne P, Waller G (2007) Probing Jamaica's Political Culture: Main Trends in the July - August 2006 Leadership and Governance Survey. Centre for Leadership and Governance, University of the West Indies.

2. Harriott A (2004) Introduction. In: Harriott A, Brathwaite F, Wortley S, eds. Crime and criminal justice in the Caribbean. Kingston: Arawak Publishers pp-1-7.

3. Simmonds LE (2004) The problem of crime in an urban slave society: Kingston in the early nineteenth century. In: Harriott A, Brathwaite F, Wortley S, eds. Crime and criminal justice in the Caribbean. Kingston: Arawak Publishers pp8-34.

4. Mars JR (2004) Police abuse of force in Guyana: Applying lessons from the United States. In: Harriott, A, Brathwaite F, Wortley S, eds. Crime and criminal justice in the Caribbean. Kingston: Arawak Publishers 206-224.

5. Robotham D (2003) Crime and public policy in Jamaica. In: Harriott A, ed Understanding crime in Jamaica: New challenges for public policy. Kingston University of the West Indies Press 197-238. 
Citation: Bournev PA, Mills M, Campbell-Smith J, Sharpe-Pryce C, Francis C, et al. (2014) The Influence of Macroeconomic Variables on Health Indices, Murder and Mortality: A Case of Jamaica. J Gen Pract 2: 145. doi: 10.4172/2329-9126.1000145

6. Headley B (1994) The Jamaican crime scene: A perspective. Mandeville: Eureka Press.

7. Sives A (2003) The historical roots of violence in Jamaica: The Hearne Report 1949. In: Harriott A, ed. Understanding crime in Jamaica: New challenges for public policy. Kingston: University of the West Indies Press 49-62.

8. Harriott A (2003) Editor's overview. In: Harriott A, ed. Understanding crime in Jamaica: New challenges for public policy. Kingston: University of the West Indies Press.

9. Figueroa M, Sives A (2003) Garrison politics and criminality in Jamaica: Does the 1997 election present a turning point? In: Harriott A, ed. Understanding crime in Jamaica: New challenges for public policy. Kingston: University of the West Indies Press 63-88.

10. Harriott $A$ (2003) Fear of criminal victimization in a reputedly violent environment. Social and Economic Studies 52: 35-71.

11. Chadee D (2003) Fear of crime and risk of victimization: An ethnic comparison. Social and Economic Studies 52: 3-98.

12. Box S, Hale C, Andrews G (1988) Explaining fear of British Journal of Criminology 28: 340-56.

13. Braungart M, Braungart R, Hoye W (1980) Age, sex and social factors in fear of crime. Sociological Focus 13: 55-66.

14. Balkin S (1979) Victimization rates, safety and fear of crime. Social Problems 26: 343-358.

15. Bridges FS, Kunselman JC (2004) Gun availability and use of guns for suicide homicide, and murder in Canada. Percept Mot Skills 98: 594-598.

16. Lester D (2000) Gun availability and the use of guns for suicide and homicide in Canada. Can J Public Health 91: 186-187.

17. Harriott A (2004) The Jamaican crime problem: Some policy consideration In: Harriott A, Brathwaite F, Wortley S, eds. Crime and criminal justice in the Caribbean. Kingston: Arawak Publishers: 238-264.

18. Bourne PA (2012) Murder and ill-health: A health crime phenomenon. J Behav Health 1: 138-146.

19. Planning Institute of Jamaica (PIOJ), Statistical Institute of Jamaica (STATIN) (1988-2011) Jamaica Survey of Living Conditions, 1989-2010. PIOJ, STATIN Kingston.

20. PIOJ (1989-2010) Economic and Social Survey of Jamaica, 1988-2009. PIOJ Kingston.

21. Bank of Jamaica (BoJ) (1981-2010) Statistical Digest, 1980-2009. Bank of Jamaica, Kingston

22. Statistical Institute of Jamaica (STATIN) (1987-2011) Demographic statistics, 1988-2010. Kingston: STATIN.

23. World Bank (2002) Jamaica Survey of Living Conditions 1988-2000. World Bank, Washington, DC

24. International Monetary Fund (IMF) (2009) World Economic Outlook, April Update. IMF, Washington, DC.

25. Levy H (1996) They cry 'respect': Urban violence and poverty in Jamaica Kingston: Department of Sociology and Social Work, the University of the West Indies, Mona.

26. Ellis H (1992) Identifying crime correlates in a developing society: A study of socio-economic and socio-demographic contributions to crime in Jamaica, 1950-84. New York: Peter Lang.

27. Stone C (1987) Crime and violence: Socio-political implication. In Phillips P, Wedderburn J (eds), Crime and violence in Jamaica: Causes and solutions. Kingston: Department of Government, the University of the West Indies.

28. Phillips P, Wedderburn J (1987) Crime and violence in Jamaica: Causes and solutions. Kingston: Department of Government, the University of the West Indies.

29. Francis A, Elvy L, Kirton C (2001) Crime in Jamaica: A preliminary analysis Second Caribbean Conference on Crime and Criminal Justice, University of the West Indies, Mona, Jamaica, 14-17 $7^{\text {th }}$ February.
30. Tapia-Granados J (2005) Increasing mortality during the expansions of the US economy, 1900-1996. Int J Epidemiol 34: 1194-202.

31. Tapia-Granados J (2008) Macroeconomic fluctuations and mortality in postwar Japan. Demography 45: 323-43.

32. Tapia-Granados J (2005) Recessions and mortality in Spain, 1980-1997. Eur J Population 21: 393-422.

33. Jones MJ (2004) From the footnotes and into the text: Victimization of Jamaican women. In: Harriott A, Brathwaite F, Wortley S, eds. Crime and criminal justice in the Caribbean. Kingston: Arawak Publishers 113-132.

34. World Health Organization (2005) Preventing Chronic Diseases a vita investment. Geneva: WHO.

35. Wilks R, Younger N, Tulloch-Reid M, McFarlane S, Francis D (2008) Jamaica health and lifestyle survey 2007-8. Technical report. Kingston: Epidemiology Research Unit, Tropical Medicine Research Institute, University of the West Indies, Mona.

36. Melville JA (2002) The impact of structural adjustment on the poor. St. Kitts and Nevis: $7^{\text {th }}$ Annual Development Conference, Eastern Caribbean Central Bank Basseterre.

37. Witter M, Anderson P (1991) The distribution of the social cost of Jamaica's Structural Adjustment, 1977-1989. PIOJ, Kingston.

38. International Monetary Fund (IMF) (2008) Jamaica: 2008 Article IV consultationStaff report. IMF Country Report No 08/199. Washington DC: IMF.

39. Claude C (2011) Anatomy of the FINSAC debtors. Kingston: The Sunday Gleaner.

40. http://www.takingresponsibility.org

41. Kirkpatrick C, Tennant D (2002) Responding to Financial Crisis: The Case of Jamaica. World Development 30: 1933-1950.

42. Stennett RR, Batchelor PM, Foga CS (1998) Stabilisation and the Jamaican Financial Sector 1991-1997. Mimeo Bank of Jamaica, Kingston.

43. Downes A (2009) The global economic crisis and Caribbean States: Impact and response. Presented at Commonwealth Secretariat Conference on the Globa Economic Crisis and Small States, London.

44. http://boj.org.jm/uploads/pdf/remittance_survey_results_2010.pdf

45. Peart K (1995) Financial reform and financial sector development in Jamaica. Social and Economic Studies 44: 1-22.

46. McBain $H$ (1997) Factors influencing the growth of financial services in Jamaica. Social and Economic Studies 46: 131-167.

47. http://www.boj.org.jm/uploads/pdf/papers_pamphlets/papers_pamphlets Essential_Facts_About_Inflation_.pdf

48. Boxill I, Lewis B, Russell R, Bailey A, Waller L et al. (2007) Political culture of democracy in Jamaica: 2006. Americas barometer. Kingston: The University of the West Indies.

49. Bourne PA (2009) Growing old in Jamaica: Population ageing and senio citizen's wellbeing. Kingston: Department of Community Health and Psychiatry the University of the West Indies, Mona

50. Macdonald G (2002) Violence and health: the ultimate public health challenge Health Promot Int 17: 293-295. 